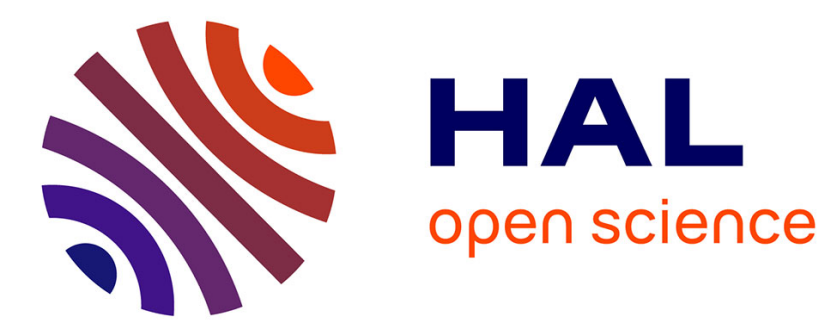

\title{
The Concept of Heritage and the Grammar of Islamic Fundamentalism
}

\author{
Baudouin Dupret, Clémentine Gutron
}

\section{To cite this version:}

Baudouin Dupret, Clémentine Gutron. The Concept of Heritage and the Grammar of Islamic Fundamentalism. Memory Studies, 2020, 14 (2), pp.483-200. 10.1177/1750698020921435 . hal-02880310

\section{HAL Id: hal-02880310 https://hal.science/hal-02880310}

Submitted on 24 Jun 2020

HAL is a multi-disciplinary open access archive for the deposit and dissemination of scientific research documents, whether they are published or not. The documents may come from teaching and research institutions in France or abroad, or from public or private research centers.
L'archive ouverte pluridisciplinaire HAL, est destinée au dépôt et à la diffusion de documents scientifiques de niveau recherche, publiés ou non, émanant des établissements d'enseignement et de recherche français ou étrangers, des laboratoires publics ou privés. 


\section{THE CONCEPT OF HERITAGE AND THE GRAMMAR OF ISLAMIC}

\section{FUNDAMENTALISM}

Baudouin Dupret, CNRS, Les Afriques dans le Monde (LAM/IEP Bordeaux), France, b.dupret@sciencespobordeaux.fr

Clémentine Gutron, CNRS, Centre Alexandre Koyré (CAK/EHESS), France, clementine.gutron@cnrs.fr

Abstract:

Islamic fundamentalism is a way to oppose the counter-narrative of an exclusive Islamic civilization to the universalist master-narrative of history's pluralistic heritage. Two methods of reading the past collide here. One is a genealogical method, which values anything that relates the present to its historical roots. The other is a fundamentalist method, which relies on sacred scriptures in order to identify a founding age it arrogates to itself and to condemn anything that does not correspond to it. These two perspectives function in a conflicting yet interdependent manner. This article aims to describe the operating modes of these two narratives. First, it examines how the concept of heritage acquired new meanings and transformed into an evaluation table with which to assess past, present, and future collective identities. Second, it describes some audiovisual productions relating to the antique city of Hatra, to the destruction of its statues by Islamic State's fighters, and to its symbolism. On this basis, it analyzes these productions in terms of heritage master- and counter-narratives. Third, it addresses, in relation to the issue of heritage, the fundamentalist discursive structure, its grammar, the entrenchment of its rules, and the demarcation it implies between the community of believers and everyone else.

Keywords:

Concept of heritage; historical ontology; Islamic fundamentalism; discursive grammar; entrenched identities

\section{1) Introduction}

The pictures of the destruction of the ancient city of Hatra's emblematic statues by members of the Islamic State (IS) were all the more iconic insofar as they accompanied rhetoric about the return of the barbarians. This was probably their authors' intention, who staged them in this way knowing precisely that they touched the core idea the West has of itself and of its past. To the master-narrative of the Mesopotamian pluralistic heritage responded thus the counter-narrative of an exclusivist Islamic civilization condemning to hell the remains of the Age of Ignorance (jâhiliyya) (see Assmann, 2004). In this dramatic 
sequence, master-narrative and counter-narrative center around the same object: the concept of heritage, and the value attached to it: authenticity.

Indeed, the concept of heritage corresponds to the legacy of the past, which is endowed with a value because it links its inheritors to their ancestors and origins; to what they think it is essentially; to what they possess specifically that defines them per se. The idea the inheritors have of themselves in the present is a response to the heritage they claim for themselves in the past. Two methods of reading the past collide here, which sometimes blend. One is a genealogical method which, based on pluralistic universalism, values anything that relates the present to its historical roots. Here, the past is teleological, entirely justified by the present to which it necessarily leads. The other is a fundamentalist method, which relies on sacred scriptures in order to identify a founding age it arrogates to itself and to exclude anything that does not correspond to it. In this case, the past is "protological", justifying whatever would befall afterward. These two perspectives function in a conflicting yet interdependent manner. They feed into each other. That is not to say that both narratives function identically, but only to stress that they proceed in an intertwined way. The former is self-avowedly historical and global: it links the "West's" common, current identity to its many yet shared ancient roots, via the retrospective depiction of the many steps that led to the present culmination. The latter is self-avowedly ahistorical and specific: it specifically relates the Muslim community to a founding past and denunciates any deviance from its original purity. This article aims to describe these operating modes.

A precautionary note is needed, here: Although we are aware that heritage cannot be reduced to mere words and face-à-face between universalists and fundamentalists, but also includes a material relationship with "things", both material and immaterial, our approach concentrates on the uses of the concept and on the polarity that can observed, in a closely documented way, between two of its many layers of understanding. It should also be clear 
that, although we focus on a specifically Islamic case of study, we do never contend - quite to the contrary - that the fundamentalist grammar we describe is specific to Islam.

We will proceed in three parts. In the first, drawing on Ian Hacking's "dynamic nominalism", we will examine the concept of heritage and observe how this legal word acquired a new meaning and transformed into a concept which functioned as an evaluation table with which to assess past, present, and future collective identities. We will also concentrate on this concept in an Islamic, Arabic-speaking environment. In the second section, we will describe some audiovisual productions relating to the Mesopotamian antique city of Hatra, to the destruction of its statues, and to its symbolism. On this basis, we analyze these productions in terms of heritage master- and counter-narratives. In the third section, we will address the Islamic fundamentalist discursive structure, its grammar, the entrenchment of its rules, and the demarcation it implies between the community of believers and everyone else.

\section{2) A historical ontology of heritage}

Heritage is not just an English word. It is a word expressing what other words in other languages, such as "patrimoine" in French or "turâth" in Arabic, express. As such, it is a concept. However, there is no physical reality corresponding to this concept, unlike the concept of a cat (or "chat", or "qitt"). The concept of heritage refers to a non-material artifact, something socially produced to express an idea, that of inheritance from a natural and cultural past (Harrisson, 2010; Smith, 2006; West, 2010; Meskell, 2011; Harrison, 2012). All the words used to express this concept of "heritage" convey the patrimonial idea of a legacy, property inherited from our ancestors. In French, the word "patrimoine" is borrowed from the notarial vocabulary and designates the wealth inherited from, and belonging to, the family. The English "heritage" and the Arabic "turâth" instead stress the idea of inheritance itself. In 
all cases, heritage is something that does not exist independent of the practices defining a social, cultural order. It acquires its status through our naming of it.

Drawing on Ian Hacking's philosophical works (1999 and 2002), we observe the interactions between our practices of naming and the things we name. In our case, it means that we scrutinize how the policies, attitudes, and practices of naming something "heritage" closely interact with the material and immaterial, natural and cultural objects so named. This is a question that calls for a historicized answer, since the coming into being of certain objects is itself thoroughly historical. "Historical ontology" is what we call the description of both the being itself and its history. Every discourse, since it is historically situated, exhibits a grammar through which concepts, some of them of a categorical nature, are constituted. Concepts and categories are historical objects that do not exist until they are created. For instance, in the past, before the concept of homosexuality was formed, there could be sexual acts between two people of the same sex, but there could not be a specific kind of person categorically called a "homosexual" (Davidson, 2001; Hacking, 2002: 82). ${ }^{\mathrm{i}}$ Historically and etymologically speaking, the many words used to express the contemporary concept of cultural heritage have existed for a long time. However, they were not used with their current meanings. We can observe a close relationship with the notion of modernity and its transformation. In France, indeed, the Revolution seems to mark a turning point, with the appearance of the term "national heritage" (patrimoine national). Between the idea of one family's wealth inherited from ascendants and the notion of national property inherited from a common past, there is what Michel Foucault (1994) called, when writing about madness, a "great divide", that is, a radical and often incommensurable discursive gap.

Monuments with a long history pre-existed the category of heritage, but there could not be a specific kind of thing called "heritage" before the category was conceived. As long as humans do not interfere with the course of things, what things do does not depend on human 
ways to describe them. However, many things do not exist as such without human characterization. In this case, one observes that particular kinds of things and persons come into being at specific moments. They do not constitute real entities waiting for their scientific discovery, but entities which, once the distinction has been made, constitute new realities which come into being (Hacking, 2002: 103) and are "an object of making-up" (id.: 104). This is an issue of "dynamic nominalism" in which "our spheres of possibility (...) are to some extent made up by our naming and what that entails" (Hacking, 2002: 113). There is no global narrative since every category has its own story, but there is nevertheless a certain scheme: some labeling from above creates realities, which certain people make their own; the autonomous behavior from below creates realities experts must face (Hacking, 2002: 111).

Discourse on heritage was made possible through the emergence of a conceptual space articulated by a style of reasoning (Davidson, 2001: xii). This is not the place to explore the complex history of the concept and of the discourse in which it is embedded. It is enough to say that it works as an "operator of meaning" about the relationship with the past, which is centered on the function of transmission: a system of transfer of collective possessions, which is seen as securing a group's identity through time (Tornatore, 2010: 108). The concept evolved, spread, and transformed itself. It became something like a performative injunction working, initially, to celebrate national cultures and, subsequently, to develop an ethics of responsibility regarding future generations. In this process, it was associated with values, which were themselves changing, but it always remained attached to an idea of truth vis-à-vis one's past and its transmission to future generations. This may be called a "relation of authenticity". Such type of relation can operate in antithetical directions, as partly illustrated below in videos capturing universalist and fundamentalist conceptions of heritage. The former conception considers authenticity in a teleological way, the past pointing to the present, the present being the necessary outcome of the past, and identity meaning to be true to one's 
pluralist self and past. On the contrary, the latter conception works in what we call a "protological" way: the present points to the Prophetic past of which it is either duplicative or deviant; the Prophetic past is the only point reference; and identity means to be true to the Prophetic model.

The emergence of the "Arab Islamic" equivalent of heritage, turâth, ${ }^{\mathrm{ii}}$ was based on the Western, late $18^{\text {th }}$ century concept's importation, appropriation, and adaptation by the reformists of the Nahda (Arab renaissance) in a colonial and later, postcolonial context. The Nahda's representatives claimed to manage the intellectual heritage of the Islamic community, the Umma, in a way that endeavored to "clean it from the slags of History" (Roussillon, 2010). Thus, from its inception, the historical ontology of heritage in Arab Islamic societies was linked to colonialism, Islam, reformism, authenticity, and national identity. The word turâth is mentioned in Ibn Mansur's encyclopedic dictionary Lisân al'Arab, which dates from the end of the $13^{\text {th }}$ century AD, and refers to both material (e.g. a son from his father) and spiritual (e.g. human people from their Creator) inheritance (Oulebsir and Swenson, 2015: 16). It was upon contact with European cultures, through both physical and cultural colonization (see e.g. Mitchell, 1988) - which explains why it also worked in this way in countries not colonized by European powers, but touched by European cultural globalization - that the word crystallized into its modern conception. ${ }^{\text {iii }}$ However, "while material heritage kept on being the business of the European administration of fine arts and antiquities established in the different countries (Iraq, Lebanon, Egypt, Tunisia, Algeria, etc.), which concentrated on antique monuments and vestiges, indigenous elites produced a patrimonial discourse based on the immaterial" (Oulebsir and Swenson, 2015: 17). Religious or profane, this discourse linked heritage to what was perceived as the Golden Age of Islamic civilization. From the late $19^{\text {th }}$ century onwards, the concept of turâth was considered "a way 
to revitalize the Arab tradition, including its Islamic component, which was favored by the rising of identity claims and of the idea of an Arab nation" (Oulebsir and Swenson, 2015: 17).

Many concepts describe certain human behavior at the same time as they evaluate it, therefore mixing facts and values (Hacking, 2002: 69). If we take the example of "heritage", we observe that, because the concept is evaluative, it has an effect upon the investigator who finds him/herself implicated in the subject itself; and because the formation of the concept has a history, it places a constraint on our present way of thinking about the object to which it applies. Thus, conducting conceptual analysis allows us to understand how we think and why seem compelled to think in certain ways (Hacking, 2002: 71). It can be done à la Foucault with snapshots taken on either side of the Great Divide, during which one tradition transformed into another, or it can be done in a synchronic way, with snapshots taken from two concurring repertoires addressing a seemingly identical concept. In both cases, the discourse must be analyzed within the circumstances and conditions under which the sentences that make it have "archeologically" acquired their truth value and could therefore be uttered (Hacking, 2002: 79). All discourse corresponds to the knowledge of a time and a place, of a community of speakers, and this knowledge determines what can be said at that historical moment. Concepts are not trans-historical entities but words in the sites in which they are used (Anscombe, 1957). Different words can express the same concept, as is the case in UNESCO documents translated into various languages. More importantly, the same words can express different concepts. Thus, concepts can create puzzles, which can be solved only through the description of their historical ontologies. Heritage, in its present international meaning, refers to monuments, places, cultures, and nature. In that respect, the word turâth has acquired three different and sometimes exclusive meanings. In the sense of cultural heritage, firstly, it appeared in the wake of European imperialism and was initially linked to the veneration of objects and monuments, something rather unknown in the colonized 
societies. It should be noted, however, that this transplant (Watson, 1974) was successful in many cases and became part of the cultural policies of independent states, as well as an integral part of local cultures ${ }^{\text {iv }}$. In a broadly defined Islamic sense, secondly, the word turâth, which was closely linked to Islamic culture, focused on the immaterial character of that which was transmitted from one generation to another, maintaining a distance vis-à-vis its material aspects and rejecting any kind of veneration of objects and pictorial representations (Oulebsir, 2004: 14-15). Thirdly, in its Islamic fundamentalist sense, turâth refers only to God's revelation (the Qur'ân), the Tradition of His Prophet (the Sunna), and the (contentiously selected) principles based on these two primary sources. However, these are three senses among many others, as Trinidad Rico nicely remarked (Rico, 2017). Moreover, to our knowledge, it never had the characteristic of collective ownership characterizing the identity of a group, i.e. the Muslim community, before the reformist movement of the late $19^{\text {th }}$-early $20^{\text {th }}$ century, which cannot itself be understood without keeping in mind that it developed against the backdrop of the European conception of heritage. We will come back to the latter conception in the third section of this paper.

The concept of heritage appeared together with a discourse on the memory of collectively owned things, e.g., buildings (Benton, 2010). It started with an ethnocentric conception of heritage comprised of all that contributed to universal (viz. Western inspired) civilization, and it transformed into a differentialist perspective promoting cultural diversity against standardizing globalization (Tornatore, 2010: 118). This had a twofold consequence. On one hand, it inspired claims of belonging to World Heritage (Labadi, 2013; Meskell, 2015). This is how several Islamic monuments came to be registered on the UNESCO list. On the other hand, it gave impetus to alternative claims using the same vocabulary of heritage to promote and value different objects. This is how the Arabic word turâth became progressively associated with the notion of Islamic values and thought. Disjunctive conceptions of heritage 
are nevertheless linked to each other. The emphasis on "Islamic turâth" does not make sense without the parallel infatuation for World Heritage. The former works as an echo of the latter, even though the sound created by the echo radically distorts the one produced by the original. Both conceptions work as the two sides of the same coin. As we shall see in section two, the destruction of statues by the Islamic State makes sense within a conflict about what is worth being sacralized: the good of one is the evil of others, and vice versa, in a tightly intertwined way.

Thinking of heritage as a kind of collective ownership was made possible in a specific social, historical framework, which transformed its patrimonial nature into an issue of national property. Initially an issue of ownership, it became an issue of identity (Fabre, 2013). Authenticity relates to essentialism and culturalism, which themselves took root in nineteenth century romanticism and nationalism. It spread to societies, which found the call for ownership of their past and of its knowledge attractive (Sharrock, 1974), especially in a colonial and postcolonial context. This evolution testifies to the redefinition of the limits of discourse about heritage, together with the social conditions in which it is embedded. The nature of heritage and thus the knowledge on which it is based are both contingent and $a$ priori, so to speak. New ways of thinking and new branches of knowledge appear, change, and disappear; new spaces of possibilities are opened, together with new criteria for questions to ask and ways to answer them (Hacking, 1999: 172). Discourse about heritage was made possible because of the emergence of a new conception of one's relationship to the past, of its inheritance and transmission, and of its ownership (making one society's identity identical to the past it owns). Such discourse has an identical matrix all over the world, but it is instantiated in radically different ways: pluralist or monist, inclusive or exclusive, differentiated or undifferentiated, contingent or ahistorical. 


\section{3) Conflicting narratives regarding heritage in the Middle-East}

Our type of study does not have the ambition to account for the totality of the phenomenon of iconoclasm in Islam. Neither does it pretend to address the issue of patrimonial universalism or Islamic fundamentalism as a whole. It nevertheless argues, in a detailed and documented way, how some instances of World Heritage and Islamic iconoclasm discourses are organized, how they offer a structure of intelligibility to their "readers", and thus how they can be potentially understood by the people who have access to the sites of their broadcasting. In other words, it proposes a methodologically valid, though limited and contingent, way to address the issue of ideological sense making in present-day heritage discourses.

At this stage, we need to make a remark as to what we mean by context in the study of media productions. Indeed, theories and conceptions of context are many (see Dupret and Ferrié, 2008). There is obviously a consensus on the necessity to consider the context as primordial, although there is little agreement on the meaning to give to such an assumption. On the one side of the spectrum, one finds a broad and all-encompassing conception of context that tends to include many layers and determinants. The context is here assimilated to the social structure. On the other side of the spectrum, there is a wholly different conception which, instead of considering that it is a structure that constrains and/or permits agents' actions, restricts it to what is publicly relevant and procedurally consequential for members. According to this conception, to which we affiliate ourselves, an analyst is not free to invoke whatever variables he/she feels appropriate as dimensions of context, but must demonstrate in the events being examined that the participants themselves are organizing their behaviour in terms of the features being described by the analyst (Duranti and Goodwin, 1992: 192). In other words, context is not an analyst but a member phenomenon, that is, the features to which the people engaged in a course of action orient as locally relevant and consequential. 
The question becomes a little bit more complicated in the case of media products, since, on the one hand, the context of their production is not relevant as to their reception, and, on the other hand, the context of their reception is as variegated as the number of their readers. Context in this perspective means the constraints that are exerted on the "readers" and on their reading by the "text" itself, by its structure of intelligibility (Jalbert, 1999). One can speak of context as the media product's affordance. Our method thus consists of not imparting any information about the context of production and/or reception beyond what may be inferred from the texts posted on the Internet in order to present themselves to their audience, to impute an identity to that audience, and to convey a message specifically addressed to this specifically identified audience. In a way, the undertaking consists of evaluating the description of naturally accessible empirical data and limiting the reflexivity of the researcher, inasmuch as it would be "an academic virtue and a source of privileged knowledge" (Lynch, 2000).

In order to prosecute this research agenda, we began to assemble a corpus of materials freely available to download from the Internet. It was mundanely apparent within minutes, having watched just a few videos, that these offered contrasting narratives regarding heritage. In terms of Livingston's laic/professional distinction, if these contrasts were mundanely apparent to us, then these intended viewings would be available to different audiences, also. Some of them advocate the promotion of heritage, others its destruction. In the praxiological attitude we just explained, we assume that people watching these videos, including ourselves, understand the stories they tell from within a grammar of ordinary sense-making practices, shared categorization devices, and a background knowledge of issues relevant for the audiences to which they belong. Thus, we start our analysis with the assumption that these videos produce a structure of relevance directly (though perhaps imperfectly) available to an ordinarily competent audience, including ourselves. In that sense, media material must be 
treated as filmic texts, that is, audio-visual material products endowed with intelligibility structures and devices (Jayyusi 1988, 1991). Engaging in the praxiological study of such "textual products" therefore means not only paying attention to their semantic dimensions, but also focusing on the categorization, sequence, publicly relevant, and procedurally consequential features within which any reading practice of the textual product is necessarily embedded. Instead of assuming what the text's author has in mind when writing or editing it, our praxiological perspective tangentially adopts the reader's natural attitude when confronted with the so-called media text. Because texts are meant to be read and understood, their complexity does not imply opacity, but on the contrary accessibility, albeit to competent readers, who read them with the means they use to understand the order and properties of the social and natural world (Jayyusi, 1984: 289).

Proceeding further in our research, we tried to locate videos addressing one and the same patrimonial object. Our data are comprised of two videos featuring the city of Hatra in present-day Iraq. ${ }^{\mathrm{v}}$ The first one was available on Youtube. ${ }^{\mathrm{vi}}$ The second one could be watched initially on Youtube and then on Jihadology, a website dedicated to the documentary production of jihadist movements. ${ }^{\mathrm{vii}}$ It is not the purpose of this paper to present these two platforms. Suffice it to characterize them roughly as being oriented toward UNESCO's discourse on World Heritage for the former and to Salafi jihadism for the latter. ${ }^{\text {viii }}$ Both broadcasters offer narratives in which they promote or condemn heritage. They use the format of short productions combining images, text, sound and music in order to convey an apologetic or blame-implicative message. We already had the opportunity to analyze this combination and the powerful effect of pictures in this type of discourse (Dupret, 2011), but for the sake of this study, we concentrate on their textual dimension.

Our aim is therefore to describe analytically the audio-video production available to members of the audience and the methods they must mobilize to understand the narrative and 
its advocacy message. It shows how these video-clips produce, and are produced by, a master narrative whose interpretation method is documentary, that is, retrospectively grounded on what is "known in common" and prospectively oriented to the further inferences it makes possible.

In this section, we examine the two selected videos and describe their socio-logic at the level of global narratives; secondly, we concentrate on the categorical and sequential organization of the narratives; and thirdly, we show how these videos are geared toward the documentary production of master-narratives, which mirror and/or counter each other.

The "World Heritage" video produces a narrative which we summarize as follows: "The city of Hatra is of special importance as it is the place where East and West met." A narrative is a threaded structure that proceeds, from an opening to a closing, through the various stages of a story presenting a surface immediately accessible to any competent reader/viewer. In this case, it starts with a title (the city where East and West met), unfolds through a visit of the site, insists on Hatra's features as a crossroads on the Silk Road and a place of co-existence, and reaches the conclusion that it was a crucible where an array of cultures and religions lived in harmony.

\section{Excerpt 1 - World Heritage: The "Cultures-In-Harmony" Narrative}

The city where East and West met: Hatra. There was once a thriving city-state called Hatra in the northern Iraqi desert. The exact details of the site weren't known until the twentieth century. An excavation team was hugely surprised when they found a Greek temple on the site. The marble columns built in Ionic style look exactly as like those found in Greece. [Bedouin music] Camel caravans passed through here for a period of several hundred years before and after Christ. The Silk Road was then a busy trade route connecting the Chinese Han and Roman empires. Hatra was an important stopover between Mesopotamia and the Mediterranean sea. The discovery of this al-Lat temple unveiled the different side of Hatra. The imposing carvings depict camels which represent wealth and affluence. This relief could represent the goddess al-Lat. The figures here are 
believed to be either of the king or an oracle. Eastern and Western civilizations met here and created a form of art known as the "Helleneastern" style, a combination of Greek Hellenism and the Eastern style from Asia. There is a two-meter high female statue in the deepest part of the sacred temple area. It is believed to be of a princess. Hellenic art is characterized by realistic representation of human form. However, the way she is holding her hand up in front of her chest is not usually seen in Hellenism. The main temple has eight arches. It is dedicated to Shamash, the supreme god of Hatra. It is possible to see how Eastern and Western culture is fused here. The face of Medusa of Greek myth is carved at the entrance, while the temple itself is built in the Iwan style from Western Asia. Each god worshiped in the vast area between Mesopotamia and the Mediterranean was enshrined here. Hatra thrived by welcoming and accepting people of different religious faiths. Only a part of the town and sacred areas have been excavated so far. Hatra was a city where an array of cultures and religions coexisted in harmony. [sound of crickets]

The "Jihadist" video produces a radically different narrative, ${ }^{\mathrm{ix}}$ which reads: "They call it heritage, we call it idols, and idols must be smashed." It starts with a dedication to God ("in the name of God the Gracious the Merciful"); indicates the places where statues can be found on the archeological site seen from above; stages two fighters wearing weapons and legitimizing their actions through references to the Qur'ân and to Islamic history; features men smashing statues; and closes with the singing of a "nasheed"x proclaiming the vanishing of falsehood.

\section{Excerpt 2 - Jihadism: The "Smashing-The-Idols" Narrative}

[caption: in the name of God the Gracious the Merciful; caption: Tiger Governorate Information Office; hightech sounds; site of Hatra seen from the sky; caption: idols and statues; sound of explosion; man speaking] [first speaker:] Praise be to God Whose protection we implore. God the most Glorified the Highest said: "The Truth has arrived and falsehood has vanished, indeed falsehood had to vanish" [Qur'ân XVII 81]. And after, the Messenger - God bless him and give him peace - sent Khalid b. al-Walîd to al-'Uzza to destroy it. And then 'Amr b. al-'Âs to Su'â to destroy it. The Islamic state sent us to these idols to break them down, as they worship something else than God. Some misbelieving organizations said that the destruction of these vestiges as they call them constitutes a war crime. But we, now, we destroy them, these vestiges, if they worship anything else than 
God the most Glorified the Highest, since we achieve our worship in all sincerity for God only. We will destroy your vestiges. We will destroy your idols in whatever place and the Islamic state will rule your lands and we will break your vestiges into pieces. [caption: the smashing of the idols; pictures of destruction of and shooting on statues and carvings] [second speaker:..] [nasheed: "God the Greatest, Smash the state of the idol"; men at work, hammering statues; shouts: God is the Greatest!]. [third speaker] The action of smashing the idols is an action in which we follow the path of our prophet Ibrahim - upon him the prayer and the peace- and of our Envoy Muhammad - God's prayer and peace upon him. Our father Ibrahim had previously destroyed the statues and rejected the adoration of associationism (shirk). When he entered Mecca, our Prophet Muhammad's - God's prayer and peace upon him - first action was to destroy the idols and he ordered to oust them out of Mecca. Praise be to God, Who made possible to us and to the soldiers of the Islamic state to erase the signposts of associationism in order to impose the rule of the Sharî‘ a of the Lord of human kind. [...] [pictures of shooting, recitation of Qur'ân XVII 81; nashîd “God the Greatest, Smash the state of the idol”]

The sequential process of these videos consists of the layout of visual units for the practical purpose of producing a global narrative. This narrative proves fully categorical. In the case of the World Heritage video, it works as a touristic guidebook introduced with a title. The whole piece progressively unfolds in the form of a city tour aiming at substantiating the initial title. In the case of the Jihadism video, it works as the implementation of an order coming from God: the verses of the Qur'ân and the references to Islamic history feature alongside (and thus legitimize) the destruction of statues. Whatever their structural differences, both videos are nothing but categorical language-games.

In both videos, categorizations are organized through the ascription of various predicates. The narrative of the World Heritage document focuses on the categorization of Hatra as a pluralistic city, whereas the Jihadism document features the destruction of statues as an activity bound to the category of "idolatry". While the former categorizes the variety of goddesses and artistic styles as a symbol of universalism, tolerance and prosperity, the latter categorizes human representations as the expression of blasphemous, "associationist"xi 
worship. In that respect, the two videos mirror each other, the former promoting pluralistic inclusiveness and the latter advocating univocal exclusiveness.

Both videos are oriented toward advocacy. This advocacy relates to the issue of heritage, its characterization, the definition of its protagonists, and the ascription of relevant responsibilities. These narratives are simply categorizations of the lifeworld with regard to this very issue of heritage. As Jayyusi (1984) emphasized, the categorization process is thoroughly moral. Like other epistemic activities, it is both constituted by, and constitutive of, the moral order. Among others, categorization is concerned with the production of authenticity. Yet, because of their different structures, the two videos operate in totally different ways. Whereas the World Heritage piece takes the form of a city tour, the Jihadism one has the form of an in situ reportage. In the former, we visit the ancient city in order to draw present-day moral conclusions. In the latter, we are taken as witnesses of present-day action justified and even made compulsory by lessons drawn from a sanctified past. In short, the same site is depicted according to the different perspectives from which it is considered. In other words, conflicts of categorization consist of the ascription and apportionment of virtue and blame to things and facts held in common. Therefore, the narratives are not primarily arguments from which conclusions can be drawn, but the redundant validation of an initial standpoint.

TV channels, websites and other media devices ascribe themselves an identity and by the same token outline the audience they purport to address. They do so by resorting to narratives such as those analyzed in this section. They strive to promote one specific narrative, which we call a master-narrative (Lynch and Bogen, 1996). Imposing one master-narrative is no selfevident undertaking, but a contested process. Of course, there can be many coexisting masternarratives but only in separate spheres of relevance. A master-narrative is established against the background of other preexisting narratives. ${ }^{\text {xii }}$ In a sort of mirror game, a master-narrative 
is necessarily, although often asymmetrically, the counter-narrative of another masternarrative $\mathrm{x}^{\mathrm{iii}}$. In our two cases, this is exemplified by the reference made by one of the three speakers in the Jihadism video to the characterization by "misbelieving organizations" of the destruction of ancient sites as war crimes. This mirror game does not mean that the scripts of all these master-narratives prove different from one another. In fact, the two videos share a broadly similar moral script: heritage is good, it reflects authenticity, it should be promoted. Therefore, it is not the heritage script which is at stake, but the incumbents of the categories: what is authentic heritage; who are the defenders of authentic heritage; what is to be done with authentic heritage? Since virtue and truth are exclusive moral values, this works in a disjunctive manner and there is no middle ground: one master-narrative's evildoers are necessarily the other's victims or heroes. This combination of a reference to an immaterial Islamic heritage (turâth) and a clear-cut demarcation between virtuous insiders and vicious enemies is blatant in nashîd productions whose format refers to Arabic poetry and thus constitutes an appeal to an Arabic-speaking, educated audience and a way to "co-opt the 'special authority' that comes with the figure of the poet in Arabic literature" (Schinis, 2017).

\section{4) Truth vs Idolatry: the Fundamentalist Grammar of Heritage}

The Islamic State (IS) justifies the destruction of cultural heritage sites by the importance it places on establishing tawhîd (the oneness of God) and eliminating shirk (associationism). Consequently, its actions in Palmyra, Nimrud and Hatra have a religiously-grounded ideological underpinning often called Jihadist Salafism. Destroying historical ruins enables IS to wipe out the traces of any previous culture or civilization, while advocating its own identity and ideology. ${ }^{\text {xiv }}$ The staging of these destructions grants IS important media coverage, allowing it to show the alternative it promotes against Western, global civilization, its paramount enemy ${ }^{\mathrm{xv}}$. This is expressed most vigorously in the hymns accompanying IS media products. As Schinis (2017) puts it, "The hymns serve as a rallying cry to their listeners, a 
call-to-arms on behalf of the terror group's military goals. More than just overt calls for war, though, anashîd [sg. nashîd] serve the group as foundational and legitimizing texts. Coded within the works of IS-produced anashîd are clues about its efforts to cast itself as the leader of global jihad." Drawing on the example of heritage, this section concentrates on the grammar of this ideology.

Fundamentalism is, in one sense at least, a specific human reading of a normative body of texts. This reading concerns an object, the origins of which some people claim to recover in a totally ahistorical way. This is the meaning of many words associated with fundamentalism, like "radicalization": getting to the root of a text, its norms, and its rules. Sharî' $a$ ) is the object of Islamic radicalization. Often translated as "Islamic law", sharî' $a$ signifies divine teaching. Its material sources are the revealed text (Qur'ân) and the Prophetic Tradition (Sunna). Islamic fundamentalism, then, is this intrinsically social process by which an individual grasps sharî'a, roughly and not in detail, of which he or she claims to have the authentic reading. Thus, a radicalized reading of the Qur'ânic verses related to associationism (shirk, see Qur'ân IV 48: 'Indeed, God does not forgive association with Him, but He forgives what is less than that for whom He wills") leads to the prohibition of animated imagery (representation of human and animal life) in Islam. This is the case in the "Smash the Idols" video. It also holds true in another video production, entitled "True History", presenting the fundamentalist reasons for the destruction of statues and idols: ${ }^{\mathrm{xvi}}$

\section{Excerpt 3 - The Foundations of Fundamentalism ("True History")}

[nashîd "In Struggle"; written text overprint]

Barbarians, fanatics, extremists, fundamentalists, Islamists, etc.

This is how Afghan Muslims were characterized in Eastern and Western media, do you know why? [pictures of the Bamyan Buddha's and their destruction]

Because they destroyed statues! 
This film does not aim to judge Muslims but to report Islâm's vision regarding a question as important as its dogma: the destruction of statues and idols.

[pictures of Bamyan and other sites of statues and tombs destruction, e.g. Timbuktu; nashîd "Our Constitution Is the Qur'ân" (dustûrunâ al-qur'ân)]

Firstly, the destruction of statues is approved by Allâh in the Qor'ân. [follows a series of Qur'ânic quotes]

The fundamentalist reading of the sacred texts claims to be authentic, both theologically and historically, in relation to its reference corpus. This body can vary in breadth. It can encompass or exclude doctrinal (fiqh) and theological (kalâm) works; it may or may not include the works on the Prophetic epic (sîra) or the circumstances of revelation (asbâb al$n u z \hat{u} l)$. On the other hand, this reading cannot free itself from the Book (mushaf). As for its relation to Tradition (sunna), it is complex, and this is around this issue that it turns for the most part. The inclusive or restricted character of the reference corpus largely determines the structure of its intelligibility. To follow our example of animated imagery, a reading that claims to be authentic will make an authoritative choice of the relevant verses and traditions (hadîth). On the one hand, it will discard the fact that the Qur'ân is not explicit on the question - as it only forbids idolatry - and will present it as unambiguous. On the other hand, it will concentrate on traditions making of "iconism" an expression of polytheism and idolatry, although, as we shall see below, counter-examples exist. It will refer in particular to hadîths and to rules reported by traditionists (e.g. Bukhârî and Muslim) and jurisconsults (e.g. Ibn al-Qayyim).

The third point concerns the methods of this authentic reading that are specific to fundamentalism. The study of the grammar of the concept reveals that, besides being about an object, it aims to strip it of interpretation; in other words, of its hermeneutics. It imposes the self-proclaimed literal reading of the reference corpus as evident, independent of all that a critical work might say about it. The possible contradictions of the Qur'ânic text or of the 
Prophetic tradition, their possible hierarchization, between general provisions and specific provisions, the historical process of their constitution, these are all elements whose relevance is discarded, with an immediate advantage at stake, that of the simplicity and economy of the argument. The burden of proving the relevance of an argument is always on the author of the argument, not on the one who refutes it. The more complex the argument is - and whatever its truth value - the greater the burden. Literalism does not really have an argument; it has the letter of the text for itself and it imposes itself, even in cases where a contradictory text could say the opposite. It claims to be the final word in the conversation and thus denies the possibility of a counter-hermeneutics. We can thus speak of the privilege of literalism. In our example of idols and statues, this means that the evidence of its prohibition will prevail over the subtleties of an argument that could lead to its authorization. The "True History" document is, in that respect, most instructive. It stages the dispute between its author and another Muslim scholar, Mohamed Bajrafil. While the latter posted a video condemning the destruction of the Bamyan Buddhas by the Talibans, the former creates a fake dialogue between himself and its straw interlocutor, and then exploits all the resources of literalism to strike down his argument:

\section{Excerpt 4 - Privilege of Literalism ("True History")}

I let you now listen to what says one of the "preachers" about Islâm and Statues.

[excerpts from Mohamed Bajrafil's video document]

[Bajrafil:] "We have, on the contrary, helped to the rescue of, how to put it?, the cultural heritages of the countries we visited." [pause and caption: Oh really?] One mistake the Taliban [pause and caption: Mistake?] they committed, one of their scams and wrongs [pause and caption: Scams and wrongs?] was to destroy the Bamyan Buddhas. [pause and caption: What a surprising statement for somebody who claims to teach us Islâm] These Buddhas, the Companions of the Prophet (sws) saw them, for there were Companions who went there. But since they are "more royalist than kings" and since they were mostly keen to make believe to the people they 
were slaughtering and subjecting that they were close to God, what did they do, they went to demolish the Bamyan Buddhas, despite the fact the Companions of the Prophet (sws) had seen them."

[caption: What is his evidence that they saw these statutes and that if they saw them they were capable to destroy them? We saw that the Prophet had precisely sent the Companions to destroy the statues, how can he claim then that the Companions left the statues? With all the proofs we saw, it becomes evident and clear that the Companions and the followers (Tabi'în) could not destroy the statues, which were too high and solid. This is how the Caliph Ar-Rasheed used axes and fire to destroy Persian statues but in vain. Al-Ma'mun also recruited manpower to destroy the pyramids of Egypt but in vain. Moreover, statues which were buried and appeared only after the end of Islamic expeditions, like the temple "Abû Simbel” in Egypt, could not be destroyed [See AzZarkalî, The Arabian Peninsula, 4/1188]. Let us listen to what has still to tell us on the same subject.] [...]

A fourth point concerns the norms of reference produced by the literalist reading associated with fundamentalism. For a statement to be able to reach the status of a rule, it is necessary that, in some way, it be detached from its raison d'être; in other words, that it becomes autonomous and entrenched from its justification (Schauer, 1991). While the fairest rule is undoubtedly the one that is constantly in agreement with its raison d'être, the strongest rule is one that is capable of imposing itself in all circumstances and therefore also when it blatantly contradicts the ratio legis which originally underlay it. A rule is a rule because the authority in charge of controlling its application does not have to systematically ask the question of its legitimacy. A rule is a rule of authority when the same authority can assert that the rule imposes itself simply because of its existence, regardless of the circumstances. The literalist reading achieved by fundamentalism produces norms that are imposed because "they are there" and because there is no need to look for their raison d'etre, which is based on divine incommensurability. It does not matter, in our example of the statues, whether the reprobation concerns living deities or remains of the past, esthetic artifacts or objects of worship, religions worth respect or harmful sectarianism; the reasons which underlie this reprobation are also irrelevant. The prohibition is total and without nuance, detached from its foundations. Thus, for instance, the rejection of associationism, which can be held as the ratio 
of the condemnation of idols, will not be considered as a reason to refrain from sacralizing the Caliph or the martyrs.

A fifth point is worth making, inspired like the previous one by the philosophy of law. This one distinguishes between primary and secondary rules (Hart, 1961). The former are substantive rules, which deal with content, offer a taxonomy of obligations and prohibitions, cover all the moral, religious, legal, and other provisions that an explicit or implicit understanding of a normative system includes. Secondary rules are, instead, the constitutive rules of the system, the rules that underlie the very existence of the system, the rules without which the system would not exist as such, and the founding rules of its identity. The norms produced by fundamentalism's literalist reading are essentially secondary rules that establish a symbolic system of reference rather than organizing the details of legal life. These rules are not necessarily numerous, they do not need to be systematically applied, but they are always mobilized and put forward in times of dispute of an old order or of establishment of a new one. Claiming to found a disembodied Islamic order, through the restoration of $\operatorname{sharî}^{`} a$ or the destruction of pre-Islamic memory places, is an example of this. This is one way to understand parts of the anashîd accompanying the "Smash the Idols" and "True History" documents:

\section{Excerpt 5 - Constitutive Idealism}

"Smash the Idols"

[...] O state of light my people you are not a wish

You are the truth, you are the answer, stand up $[\ldots]$

"True History"

Our constitution, our constitution, our constitution is the Qur'an [...]

Our Islam is our constitution, our Qur'an is our criterion 
Its verses are balanced and mercy comes from our Lord

Our spring is made of its verses and perfection is under its shadow

Justice is straight in us and its balance is faith $[\ldots]$

From the preceding five points, a sixth follows: it is not so much the content of the norm of reference that counts as the perspective one has on it. The constitutive idealism of the fundamentalist normative system is a perspective on the norms of reference, which makes it possible to found a demarcated world whose object of demarcation is less important than the symbolic fracture which it establishes in an absolute manner. It is therefore the production of a new episteme from which a different world must take shape, a world inhabited by a human species distinct from the rest, that of "authentic Muslims" whose principle is not belonging to common humanity but belonging to "true Islam", to the exclusion of all others. The anashîd shed spectacular light on the demarcating line between the members belonging to a community and its outsiders, between the in-group and the out-group. The Islamic State's anashîd are noteworthy cultural artifacts aimed at characterizing both the in-group and the out-group, in a contrastive way, creating legitimacy for the former and contrasting it with the illegitimacy of the latter. As Schinis (2017) puts it, anashîd speak to their "audience, calling to the listener as a 'brother' and speaking of 'us' in the collective throughout. This call to community glorifies the battles that IS carries out and serves to invite the listeners to picture themselves in that same role, undertaking those same deeds, and earning for themselves that same glory."

\section{Excerpt 6 - Demarcation}

"Smash the Idols"

God the greatest, smash, smash the state of the idol

Hell is in need of idols and firewood

Destroy the idols of America and of its people 
There is no survival for the soldiers of lying and lies $[\ldots]$

Taste the punishment of the soldiers of polytheism I do not see

But the remains of the bones of Abû Lahab ${ }^{\mathrm{xvii}}[\ldots]$

"True History"

$[\ldots]$ He who wishes to belong to its enemy is a demon $[\ldots]$

Guidance to our people and failure to their disbelief [...]

Our adversaries are in humiliation and their leader is a demon

The great and the small, there is distraction in its darkness

Their constitution is their abomination and the law of the pirates

Those like them have been destroyed in the darkness of ages.

Transitivity, literalist privilege, rule entrenchment, constitutive idealism, and demarcation are the cornerstones of the fundamentalist reading and structuring of its own normative sources.

\section{5) There Must Be Two to Tango: Heritage as a Joint Battleground for Conflicting}

\section{Authenticities}

Advocacy video documents aim to present a viewpoint on a controversial question. They do so in an overdetermined manner. They constitute moral narratives, which are by nature truth claims. We must pay attention to these claims as situated practices, that is, as a contextual achievement of media producers and audiences. The production of these types of narratives which convey truth claims, e.g. regarding what is authentic heritage, are important political means in the hands of their broadcasters. They seek to normalize one version of the truth, that is, to ensure that the promoted narrative becomes taken for granted. Foregrounding one narrative among many amounts to elevating it to the status of an authoritative argument (Dupret and Drieskens, 2008), something that is strengthened by the iteration potential of these documents on the Internet. 
Imposing a counter-narrative means substituting one narrative with another. This can consist of a 'revolutionary conceptualization' (Stetson, 1999: 92), but can also work within a relatively similar conceptual framework. In our case, it is not the value of heritage that is questioned, but the incumbents of the constituents of authentic heritage. In other words, the conceptual structure is identical: heritage is about transmission from past to future generations; heritage is a collective ownership that defines a collective identity; while historically specific, heritage has a universal claim; heritage reflects an authentic relationship with oneself; heritage must be preserved. However, the categories constitutive of the conceptual structure are substantiated in a contrastive and even disjunctive way: the pluralism of the cultural heritage master-narrative is substituted with the monism of the Islamic turâth counter-narrative; the inclusive, extrovert universalism of the cultural heritage masternarrative is replaced by the exclusive, introvert universalism of the Islamic turâth counternarrative. In a kind of mirror-game, both discourses present the inverted image of each other. Of course, one should add: heritage incumbency is a language game and, as such, a normative game, which means, a highly political issue. It turns around the question of who masters the rules, defines the game, and ascribes incumbency.

The insistence of the fundamentalist discourse on heritage cannot be explained without the existence of its cultural heritage counterpart. This is explicitly exemplified in the Smash-theIdols document when one of the fighters who is vocal against the statues alludes to international law and its characterization of the Islamic State's destructions of ancient sites as war crimes; or in the True-History document when it concludes by condemning the UN for the protection of religious diversity. It also runs implicitly through all the documents with the production of images, texts and songs which do not make sense without the master-narrative on heritage they both duplicate and oppose. Heritage, here, has no intrinsic moral value, it is 
neither positive or negative per se, it is what people make it to be, sometimes in contrastive or even conflicting ways.

In this essay, we have seen how the Islamist discourse, as fundamentalist as it is, hinges on the universalist discourse of modernity. Therefore, it is not wrong to speak of the fundamentalist avatar of modernity. The concept of cultural heritage belongs to this panoply of new "kinds", to use Hacking's terminology, whose birth accompanies the emergence of a new discourse. These new kinds of objects and people appear, evolve and disappear, they transform in contact with each other, sometimes in a confrontational way. In any case, the counter-narrative takes its meaning only to the extent of the master-narrative that it intends to contradict; and to the extent of the same basic concept to which it ascribes a radically different content. In this sense, the hyper-valuation of the concept of cultural heritage works as a foundation for the hyper-radicalization of its Islamist denunciation.

The master/counter-narrative game on which we shed some light, although it does not invite to optimism as to the capacity to go beyond the radical confrontation opposing these mirror-representations, has major implications as to studies addressing the phenomenon of memory language games. Mirror-representations do not only co-exist, they nurture each other in a functional way, that is, in a way whose function is to perpetuate and increase antagonism (Tolan, 2017; Dupret, 2011). The capacity to loosen the knot does not consist of any kind of accommodation of the two narratives, as they are meant to oppose each other. If there is a solution, it seems to be searched rather on the side of an exit from the principled opposition between the two camps, not on that of the content of this opposition.

\section{References}

Anscombe, G.E.M.1957. Intention. Oxford: Blackwell. 
Assmann J. 2004. “Monotheism and Polytheism”. In S.I. Johnston (ed.), Religions of the Ancient World. A Guide. Cambridge: Cambridge University Press.

Benton, T., 2010, Understanding heritage and memory. Manchester: Manchester University Press.

Campion K. 2017. "Blast through the Past: Terrorist Attacks on Art and Antiquities as a Reconquest of the Modern Jihadi Identity". Perspectives on Terrorism 11(1): 26-39.

Colla E. 2015. "On the Iconoclasm of ISIS". Accessed 26 March 2019 http://www.elliottcolla.com/blog/2015/3/27/pm0t4j35d00plvir68mkffl6fyquh0

Crombie, A.C. 1988. "Designed in the Mind: Western visions of science, nature and humankind". History of Science 24: 1-12.

David, G., and Jalbert, P. 2008. "Undoing degradation: The attempted rehumanization of Arab and Muslim Americans". Ethnographic Studies 10: 23-47.

Davidson, A.I. 2001. The emergence of sexuality: Historical epistemology and the formation of concepts. Cambridge: Harvard University Press.

Dupret, B., and Drieskens, B. 2008. “Introduction”. In B. Dupret, B. Drieskens, A. Moors (eds), Narratives of truth in Islamic law. London: I.B. Tauris.

Dupret, B., and Ferrié, J.N. 2008. "Legislating at the shopfloor level: The Relevant Context of Parliamentary Debates”. Journal of Pragmatics 40: 960-978.

Dupret, B., and D'hondt, S. 2019. “L'écrasement fondamentaliste de l'histoire. Islamisme, idoles et Age de l'ignorance". Afriques (forthcoming). 
Dupret, B., 2011, Practices of Truth: An Ethnomethodological Inquiry into Arab Contexts, Amsterdam: Benjamins.

Duranti, A., and Goodwin, C., 1992, “Editors' introduction to E. Schegloff's In another context", in A. Duranti and C. Goodwin (eds.), Rethinking context: Language as an interactive phenomenon, Cambridge: Cambridge University Press,.

Fabre, D. (eds.), 2013, Emotions patrimoniales, Paris, Éditions de la Maison des sciences de l'homme, coll. «Ethnologie de la France », cahier $n^{\circ} 27$.

Flood, F. B. 2002. "Between Cult and Culture: Bamiyan, Islamic Iconoclasm, and the Museum”. The Art Bulletin 84(4): 641-659.

Foucault, M., 1994, Dits et écrits, Paris, Gallimard, coll. Quarto, vol. 2.

Garfinkel, H. 1956. "Conditions of Successful Degradation Ceremonies". American Journal of Sociology 61(5) ; 420-424.

Hacking, I. 1999. The social construction of what? Harvard: Harvard University Press.

Hacking, I. 2002. Historical ontology. Cambridge: Harvard University Press.

Harrison R., 2010, Understanding the politics of heritage. Manchester: Manchester University Press.

Harrison R., 2012. Heritage: Critical Approaches. London: Routledge.

Hart, H.L.A. 1961. The concept of law. Oxford: Oxford University Press.

Hodgson, G. S. 1964. "Islâm and Image". History of Religions 3(2): 220-260.Jayyusi, L. 1984. Categorization and the moral order. Boston: Routledge \& Kegan Paul. 
Jalbert, P. 1999. "Critique and analysis in media studies: Media criticism as practical action".

Jayyusi, L. 1988. "Towards a socio-logic of the film text". Semiotica 68(3-4): 271-296.

Jayyusi, L. 1991. "The reflexive nexus: Photo-practice and natural history". Continuum: The Australian Journal of Media \& Culture 6(2) [Internet].

Kraidy, M. 2017. “The projectilic image: Islamic state's digital visual warfare and global networked affect ». Media, Culture \& Society 39(8): 1194-1209.

Kraidy, M. 2018. "Fun against fear in the Caliphate: Islamic State's spectacle and counterspectacle". Critical Studies in Communication 35(1): 40-56.

Labadi, S., 2013, UNESCO, Heritage and Outstanding universal value. AltaMira Press.

Lynch, M., 2000, “Against Reflexivity as an Academic Virtue and Source of Privileged Knowledge" Theory, Culture \& Society 17(3): 26-54.

Lynch, M. and Bogen, D. 1996. The Spectacle of History: Speech, Text, and Memory at the Iran-contra Hearings. Durham: Duke University Press.

McLaughlin, F. 2015, «Linguistic warscapes of northern Mali » Linguistic Landscape 1(3): 213-242.

Meskell, L. 2011. The Nature of Heritage: The New South Africa. Oxford: Wiley, Blackwell.

Meskell L. 2015. Global Heritage : A Reader. Oxford :Wiley Blackwell.

Mitchell, T. 1988. Colonising Egypt. Berkeley: University of California Press. 
Mondzain M.J. 2002. L'image peut-elle tuer? Paris: Bayard.

Oulebsir, N. and Swenson, A. 2015. "Patrimoine : voyages des mots. Heritage, Erbe, Beni culturali, Turâth, Tigemmi”. Patrimoine et Architecture 21-22: 10-23

Oulebsir, N., 2004. Les usages du patrimoine : Monuments, musées et politique en Algérie (1830-1930). Paris: Éditions de la Maison des sciences de l'homme.

Rico, T. (Ed.) 2017. The Making of Islamic Heritage: Muslim Pasts and Heritage Presents. New York: Palgrave Macmillan.

Roussillon, A. 2010. “A propos de quelques paradoxes de l'appropriation identitaire du patrimoine", in R. Cattedra \& al., Patrimoines en situations. Constructions et usages en différents contextes urbains, Beyrtouh, IFPO.

Schauer, F. 1991. Playing by the rules: A philosophical examination of rule-based decision-making in law and in life. Oxford: Clarendon Press.

Schinis, 2017. "Hymnal propaganda: A closer look at clanging the swords". Jihadology.net (guestpost on October 16, 2017, retrieved on November 29, 2017). http://jihadology.net/2017/10/16/guest-post-hymnal-propaganda-a-closer-look-at-clanging-of$\underline{\text { the-swords/ }}$

Searle, John R. 1995. The Construction of Social Reality. London: Penguin.

Sharrock, W. 1974. “On owning knowledge”. In R. Turner (ed.), Ethnomethodology. Harmondsworth: Penguin Books.

Smith L., 2006, Uses of Heritage. London: Routledge. 
Stetson, J. 1999. "Victim, offender and witness in the emplotment of news stories". In P. Jalbert (ed.), Media studies: Ethnomethodological approaches. Lanham: University Press of America.

Tolan, J., 2017, «L'islam: le même et l'autre de l'Europe », in É. François and T. Serrier (eds), Europa notre histoire, Paris: Les Arènes.

Tornatore, J.-L., 2010, « L'esprit de patrimoine », Terrain, n $^{\circ} 55$ : 106-127.

Watson, A. 1974. Legal transplants: An approach to comparative law. Athens: University of Georgia Press.

West, S., 2010, Understanding heritage in practice. Manchester: Manchester University Press. 
Baudouin Dupret is educated in Law, Islamic Sciences and Political Sciences. He is Directeur de Recherche at the French National Centre for Scientific Research (CNRS) and guest lecturer at the University of Louvain (Belgium). He has published extensively in the field of the sociology and anthropology of law, legislation and media, especially in the Middle East, e.g. Practices of Truth: An Ethnomethodological Inquiry into Arab Settings (Benjamins, 2011), Adjudication in Action: An Ethnomethodology of Law, Moral and Justice (Routledge, 2011), and What Is the Sharia? (Hurst, 2017).

Clémentine Gutron is an historian, Chargée de recherche at the French National Center for Scientific Research (CNRS), based at the Centre Alexandre Koyré at EHESS (Paris), where she steers a research program on the history of archeological knowledge and heritage practices in North Africa. She is the author of L'Archéologie en Tunisie. Jeux généalogiques sur l'Antiquité (Karthala, 2010). She co-authored with Baudouin Dupret "Islamic Positivism and Scientific Truth: Qur'an and Archeology in a Creationist Documentary Film" (Human Studies, 39(4): 621-643).

\footnotetext{
'We do not use the phrase "social construction", following Searle's and Hacking's critiques of its overextensive, abusive, and tautological uses. Cf. Searle, 1995; Hacking, 1999.

ii That is: turâth is used as an equivalent to the concept of heritage in Muslim-majority societies sharing the use of Arabic, in one of its many variants.

iii In the both praxiological and historically ontological perspective which is ours, modernity must be understood as a specific moment in history, an intellectual project, and a whole set of rationalizing practices, stretching from hygiene and medicine to governance and law.

iv This idea of a local conception of heritage is utterly important in order to understand how a global concept adapts to contextually contingent conditions. It might be argued, as one reviewer of this article did, that "local heritage" plays a vital role. Actually, we contend that it is the proper of any concept, like heritage, to have an historical ontology, that is, a being that transforms punctually and locally.

${ }^{v}$ Known today in Arabic as al-Hadr, Hatra was the capital of the Kingdom of Araba and a frontier city of the Parthian Empire, which flourished in the $2^{d}$ century AD and was deserted in the $3^{d}$ century. It was rediscovered and excavated by German archeologists in the nineteenth century and inscribed on the UNESCO World Heritage Site in 1985. After North-Western Iraq was seized by IS, Hatra became a target of its iconoclast campaigns and, on 7 March 2015, Iraqi sources reported that its ruins were under attack.

vi https://www.youtube.com/watch?v=bWKb8NSq9VE, retrieved on November 13, 2017. Transcribed from English.

vii http://jihadology.net/?s=video++idols, retrieved on November 13, 2017. Translated from Arabic.

viii The Islamic State's specific strategy regarding antiquities can be explained in many ways. Formerly, it was often argued that politico-military and economic arguments were the main factors. Another argument was of a more theological nature (Hodgson, 1964). It referred to Islamic iconoclasm and stated that animal and human representations were targeted because of the reverence of which they were the object. Islamic iconoclasm inverts the process and celebrates Jihadists' victory over impiety (Flood, 2002; Colla, 2015). More recently, it was also argued that Jihadi iconoclasm could be the outcome of fierce intra-jihadist competition (Campion, 2017).

${ }^{\mathrm{ix}}$ On the images and the spectacle produced by the Islamic State, see e.g. Kraidy, 2017 and 2018.

${ }^{x}$ From the Arabic nashid, pl. anâshîd: "a vocalized chant, frequently polyphonic and often without any instrumentation" (Schinis, 2017).

${ }^{\mathrm{x}}$ That is, associating other human or animal figures to the one God.

xii This is close to what Garfinkel (1956) describes as "conditions of successful degradation ceremonies" and what David and Jalbert (2008) insightfully called "undoing degradation".

xiii See also what Marwan M. Kraidy calls "spectacle and counter-spectacle", https://www.asc.upenn.edu/newsevents/news/marwan-m-kraidy-receives-andrew-carnegie-fellowship-study-spectacle-islamic-state, retrieved November 27, 2017.

${ }^{x i v}$ On this double movement of erasure of non-Islamic remnants and inscription of an Islamic space, see Maclaughlin, 2015, and Dupret and D’hondt, 2019).

${ }^{x v}$ On the instrumental use jihadists make of pictures, see Mondzain, 2002.
} 
xvi https://www.youtube.com/watch?v=uTRFIkia3QQ, retrieved on November 23, 2017. Translated from French.

xvii ‘Abd al-'Uzza b. 'Abd al-Muttalib b. Hishâm al-Qurayshî (d. 624), paternal uncle of Muhammad, nicknamed Father of Fire (Abu Lahab) for his virulent opposition to the Prophet. His condemnation is explicit in Qur'ân CXI (The Rope). 